\title{
Wear Properties of Ti-Based Biomaterials
}

\author{
Fehim Findik* \\ BIMAS-RC Research Center, Sakarya University, Esentepe Campus, 54187 Sakarya, Turkey
}

Submission: February 06, 2018; Published: February 16, 2018

*Corresponding author: Fehim Findik, BIMAS-RC Research Center, Sakarya University, Esentepe Campus, 54187 Sakarya, Turkey,

Email: findik@sakarya.edu.tr

Abstract

The purpose of this study is to review the present wear of Ti-based biomaterials. The material properties and circumstances are affected by the type of alloys established and production processes. A short assessment of numerous test procedures and wear characterization methods are presented to define the wear performance of Ti-based biomaterials.

Keywords: Ti-based biomaterial; Wear; Friction

\section{Introduction}

Several properties such as proper strength, high corrosion resistance, biocompatibility, low friction and high wear resistance are required for the biomaterials [1]. Though, the several developed biomaterials do not fulfil all of the above necessities. Wear and corrosion have been stated to be the main causes for the failure of implant components. Some of the claims of tribology in the biomedical field are as follows: wear of dentures [2], heart valves [3], plates and screws in bone fracture repair [4]. Wear is a main influence in monitoring and defining the longstanding medical performance of a metallic biomaterial. Therefore, the aim of this study is to outline the wear characteristics of Ti-based biomaterials and how wear is influenced by the kind of alloys, production processes, test methods, and characterization practices.

\section{Desired Properties of Biomaterials} [5].

A biomaterial should fulfil the principles given underneath

I. Mechanical properties: Similar elastic modulus of biomaterials to bone (4-30 GPa) is required to inhibit stress shielding.

II. Biocompatibility: The biomaterial should be compatible with living systems.

III. High wear resistance: A high wear resistance and low friction coefficient are needed when sliding against body tissues to protect loosing of the implants.

IV. High corrosion resistance: In case of having a low corrosion resistance can release metal ions into the body producing toxic reactions.
V. Osseointegration: Osseointegration is "a direct structural and functional connection between ordered, living bone and the surface of a load-carrying implant". The roughness, chemistry, and topography of the surface play a chief role in good osseointegration.

VI. Non-toxic: The material should be neither genotoxic nor cytotoxic.

VII. Long fatigue life: A high resistance to failure by fatigue is essential to avoid implant failure.

\section{Wear of Ti-based Biomaterials}

The wear resistance of the biomaterial is important in the working of the material. Therefore, the wear resistance of a biomaterial is essential. Numerous investigations have been performed to study the tribological properties of established biomaterials.

\section{Wear testing methods}

The methods that are generally utilized in the previous work to investigate the tribological performance of metallic biomaterials are the block-on-disc [6], ball-on-disc [7], and pinon-disc [8], as shown in Figure 1.

\section{Characterization techniques for the wear of biomaterials}

Chemical analyses eg energy-dispersive spectroscopy (EDS)] have been employed for selected regions to define the composition. A scanning electron microscope (SEM) has been utilized to monitor the wear mechanism. A 3D Talysurf tool has been used to examine the 3D surface roughness [5]. 

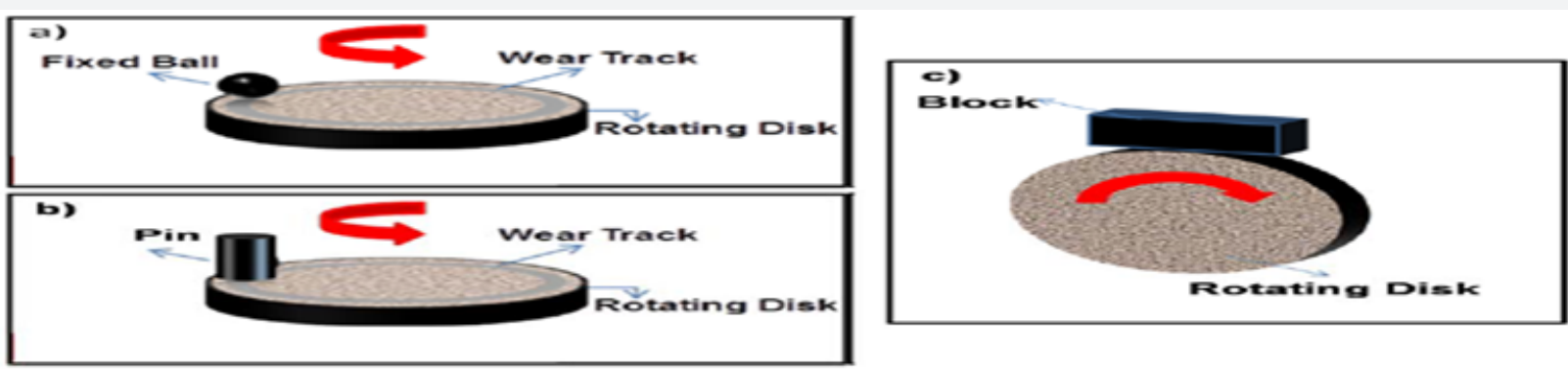

Figure 1: Schematic of (a) ball-on-disc, (b) pin-on-disc, and (c) block-on-disc wear test configurations.

\section{Wear Performance of Different Biomaterials}

Increasing the $\mathrm{Nb}$ content improved the wear resistance of Ti-based alloys [8]. Heat treatment improved the resistance to wear of Ti-29Nb-X due to the formation of oxide particles from $\mathrm{Nb205}$. The tribological characteristics of commercially pure Ti, Ti-Al-V, and Ti-Al-Fe were studied in Hanks's solution [9]. Wear mechanisms were detected as tribo-mechanical abrasion, transfer layer formation, and cracking. Comparison of the tribological behavior of Ti-13Nb-X and Ti-6Al-X was done under diverse heat treatment conditions [6]. The wear resistance of the Ti-6Al-X alloy was observed as higher to that of the Ti$13 \mathrm{Nb}-13 \mathrm{Zr}$ alloy under all of the heat treatment conditions. The wear resistance of Ti-15Mo-XNb alloys was studied [10] under dry conditions. The friction coefficient was observed to increase with the $\mathrm{Nb}$ content. Adhesive wear was observed to be the primary wear mechanism. Also, the wear behavior of Ti-6Al-XNb and AISI 316L stainless steel alloys was studied at dissimilar sliding speeds and loads [11]. The similar friction and wear mechanisms were detected for the examined specimens. An increase in the friction coefficient with the sliding speed was observed for both alloys.

\section{Techniques to improve wear resistance of metallic biomaterials}

Several modification methods for the surface can be mentioned as ion implantation, nitriding, carburizing and plasma coating used to improve the wear resistance of biomaterials [5].

\section{Summary}

I. Addition of $\mathrm{Nb}$ to Ti alloys improves the wear resistance of these alloys and rises the friction coefficient due to the increment with the alloy hardness.

II. Abrasive wear has been detected to be the principal wear mechanism.
III. To develop the resistance of alloys to wear and friction, surface treatments and coating are essential.

\section{References}

1. Patel NR, Gohil PP (2012) A review on biomaterials: Scope. Application s \& human anatomy significance. Int J Emerg Technol Adv Eng 2: 91101.

2. Litonjua LA, Andreana S, Bush PJ, Cohen RE (2003) Tooth wear: Attrition, erosion, and abrasion. Quintessence Int 34: 435-446.

3. Reul H, Schmitz C, Pfaff EM, Hohlstein C, Schmidt PA, et al. (2002) In-vitro assessment of the wear development mechanism and stabilization of wear in the Edwards MIRA/Sorin Bicarbon mechanical heart valve orifice ring. J Heart Valve Dis 11: 409-418.

4. Shahgaldi BF, Compson J (2000) Wear and corrosion of sliding counterparts of stainless-steel hip screw-plates. Injury 31: 85-92.

5. Hussein MA, Mohammed AS, Al-Aqeeli (2015) Wear characteristics of metallic biomaterials: a review. Materials 8: 2749-2768.

6. Cvijovic AI, Cvijovic Z, Mitrovic S, Rakin M, Veljovic D, et al. (2010) Tribological behavior of orthopedic Ti-13Nb-13Zr and Ti-6Al-4V alloys. Tribol Lett 40: 59-70.

7. Muñoz AI (2011) Effect of the environment on wear ranking and corrosion of biomedical CoCrMo alloys. J Mater Sci Mater Med 22: 437450 .

8. Li SJ, Yang R, Li S, Hao YL, Cui YY, et al. (2004) Wear characteristics of Ti-Nb-Ta-Zr and Ti-6Al-4V alloys for biomedical applications. Wear 257: 869-876.

9. Choubey A, Basu B, Balasubramaniam R (2005) Tribological behavior of Ti-based alloys in simulated body fluid solution at fretting contacts. Trends Biomater. Artif Organs 18: 141-147.

10.Xu L, Xiao S, Tian J, Chen Y (2013) Microstructure, mechanical properties and dry wear resistance of $\beta$-type Ti-15Mo-xNb alloys for biomedical applications. Trans Nonferrous Met Soc China 23: 692-698.

11. Fellah M, Labaïz M, Assala O, Iost A (2014) Comparative Tribological study of biomaterials AISI 316L and Ti-6Al-7Nb. TMS pp. 237-246. 


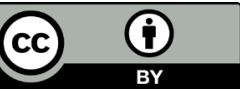

his work is licensed under Creative Commons Attribution 4.0 License

DOI: 10.19080/CTBEB.2018.12.555837
Your next submission with Juniper Publishers will reach you the below assets

- Quality Editorial service

- Swift Peer Review

- Reprints availability

- E-prints Service

- Manuscript Podcast for convenient understanding

- Global attainment for your research

- Manuscript accessibility in different formats (Pdf, E-pub, Full Text, Audio)

- Unceasing customer service

Track the below URL for one-step submission https://juniperpublishers.com/online-submission.php 